\title{
Effects of soil water content and light intensity on the growth of Molinia japonica in montane wetlands in South Korea
}

\author{
Yu Seong Choi ${ }^{1}$, Hyun Jun Park ${ }^{1}$ and Jae Geun Kim ${ }^{1,2^{*}}$ (D)
}

\begin{abstract}
Background: Montane wetlands are unique wetland ecosystems with distinct physicochemical characteristics, and Molinia japonica often makes dominant communities in montane wetlands in South Korea. In order to figure out the environmental characteristics of $M$. japonica habitats and the major factors for the growth of $M$. japonica, field surveys were conducted in five wetlands from September to October 2019. Also, soil was collected at every quadrats installed in surveyed wetlands to analyze the physicochemical features.
\end{abstract}

Results: The relative coverage of M. japonica was higher in low latitude wetlands than in high latitude. Redundancy analysis showed that soil water content had the strongest effect on the growth of $M$. japonica $(F=23.0, p<0.001)$. Soil water content, loss on ignition, and relative light intensity showed a high correlation with the density $(R=$ $0.568,0.550,0.547$, respectively, $p<0.01)$ and the coverage of $M$. japonica $(R=0.495,0.385,0.514$, respectively, $p<$ $0.01)$. Soil water content, loss on ignition, and $\mathrm{pH}$ were highly correlated with each other.

Conclusions: Molinia japonica lives in acidic wetlands at high altitude in temperate zone of low latitude, with peat layer placed on the floor. Also, M. japonica prefers open spaces to secure enough light for photosynthesis. High shoot production of $M$. japonica resulted in adding new peat material in every year, and this layer enforces the environmental characteristics of $M$. japonica habitats. This study may provide insights for further understanding of the method how wetlands maintain acidic condition by itself in montane wetlands in temperate zone.

Keywords: Redundancy analysis, High altitude, Montane wetland, Peat, pH, Relative light intensity, Soil water content

\section{Background}

Montane wetlands in temperate zone are characterized by relatively low temperature and low $\mathrm{pH}$, reduced decomposition rate of organic matter by saturation of water, and formation of peat layers, causing specific plants adapted to this environment to live (Kim et al. 2014). Distributed in high degree of elevation while forming a unique ecosystem blocked from outside, montane wetlands have a high value because they function as

\footnotetext{
* Correspondence: jaegkim@snu.ac.kr

'Department of Biology Education, Seoul National University, Seoul 08826, Republic of Korea

${ }^{2}$ Center for Education Research, Seoul National University, Seoul 08826, Republic of Korea
}

(c) The Author(s). 2021 Open Access This article is licensed under a Creative Commons Attribution 4.0 International License, which permits use, sharing, adaptation, distribution and reproduction in any medium or format, as long as you give appropriate credit to the original author(s) and the source, provide a link to the Creative Commons licence, and indicate if changes were made. The images or other third party material in this article are included in the article's Creative Commons licence, unless indicated otherwise in a credit line to the material. If material is not included in the article's Creative Commons licence and your intended use is not permitted by statutory regulation or exceeds the permitted use, you will need to obtain permission directly from the copyright holder. To view a copy of this licence, visit http://creativecommons.org/licenses/by/4.0/.

a gene pool of distinctive species (Kim et al. 2015). Montane wetlands are classified into bog, fen, and marsh according to the characteristics of their substrate, but they mostly have precipitation and groundwater as the main source of water regardless of wetland types (Ryan et al. 2014; Ahn et al. 2016). Hence, montane wetlands are prone to exposure to dry conditions and are highly sensitive to environmental changes than other wetlands. Therefore, it is necessary to understand the environmental characteristics of montane wetlands preferentially for precise and detailed prediction of future changes.

Among various biotic factors in montane wetlands, vegetation is most closely related to the hydrological characteristics of montane wetlands (Koerselman et al. 
1990; Crowe and Clausnitzer 1997; Park et al. 2013). In particular, dominant plant species, having an important role in vegetation structure, can affect significantly both biotic and abiotic factors, and vice versa (Tscharntke 1992). Because of their high proportion of biomass in community, changes in dominant species by environmental factors often cause several consequences in community level (Berendse 1998; Koukoura et al. 2003). Additionally, alterations in abiotic factors including soil characteristics caused by dominant plant species can act as selective forces to other species (He et al. 2008; Mulhouse et al. 2005). Considering these facts, understanding ecological characteristics of dominant plant species in montane wetlands is of importance, yet little understanding has been made (Moon and Koo 2014; Kim et al. 2015). Therefore, approaches to examine the ecological characteristics of typical dominant species are needed.

Molinia japonica Hack., distributed in various sites in South Korea and Japan, is one of the most common dominant plant species of montane wetlands in South Korea (Kim et al. 2005). They grow about $30 \sim 110 \mathrm{~cm}$ and tend to form many hummocks, growing together in dense form (Lee 2003). Also, they produce a lot of shoots and expected to play a major role in the plant community of montane wetland. Nevertheless, information about their growth characteristics is very insufficient, and they are only included in the vegetation list of the studies focusing on other factors of wetlands ( $\mathrm{Yi}$ and Nam 2008; Choung et al. 2009; Park et al. 2011). Here, our study first examined the growth characteristics of $M$. japonica and the most influential abiotic factors for the plant species.

In this study, field survey was conducted in several montane wetlands in South Korea to identify the growth characteristics of $M$. japonica. The purpose of our study was to identify the environmental variables important for the growth of $M$. japonica. It is believed that this study will enable to figure out the overall growth characteristics of $M$. japonica and provide basic data to understand the environment of montane wetlands in South Korea.

\section{Materials and methods}

\section{Study sites}

Based on literature research and field investigation, 13 montane wetlands located in the country were identified. Considering the possibility of access and community survey, and the size of $M$. japonica dominant community, five wetlands were selected as study sites: wetlands in Mt. Horyonggok (HRG) (26 m asl), Mt. Chilbo (CB) (120 m asl), Mt. Geumjeong (GJ) $(560 \mathrm{~m}$ asl), Mt. Hwangmae (HM) (760 m asl), and Mt. Sinbul

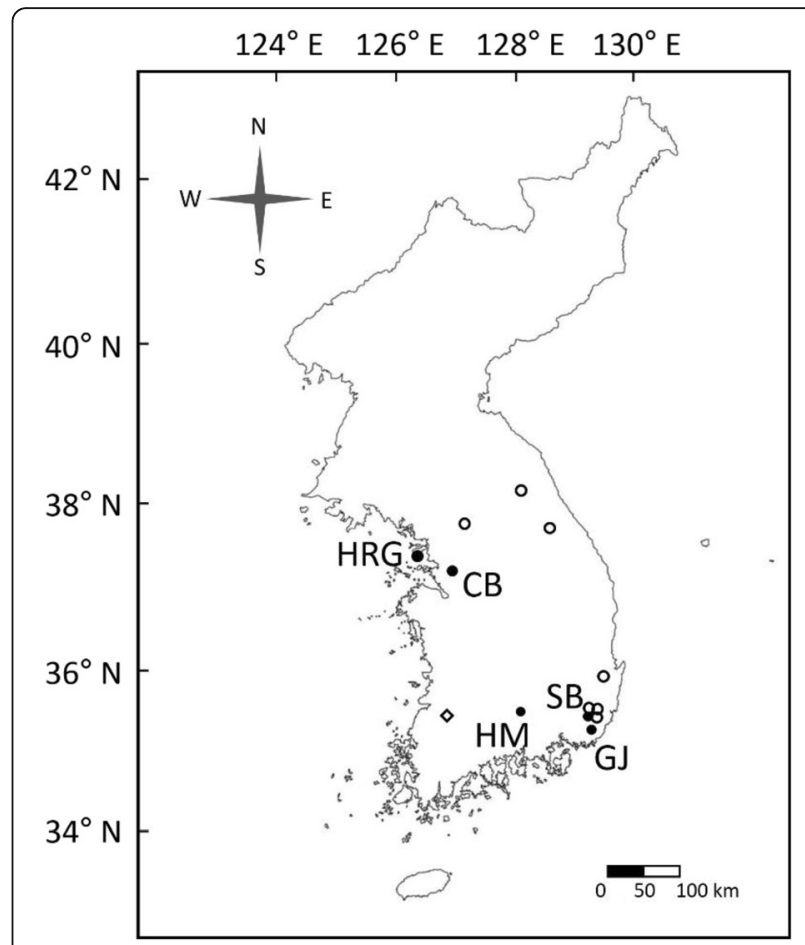

Fig. 1 Study sites of M. japonica; HRG, wetland in Mt. Horyonggok; $\mathrm{CB}$, wetland in Mt. Chilbo; GJ, wetland in Mt. Geumjeong; HM. wetland in Mt. Hwangmae; SB, wetland in Mt. Sinbul; black circle indicates study sites; white circle indicates $M$. japonica habitats where vegetation survey could not be done; white diamond indicates the site known as M. japonica habitat by literature, but not in present

(SB) (739 $\mathrm{m}$ asl) (Fig. 1). HRG and CB are in relatively high latitude and low altitude than GJ, HM, and SB. Molinia japonica was not dominant in wetlands in high latitude and high altitude and not found in wetlands in low latitude and low altitude. Phragmites australis, Oplismenus undulatifolius, Potentilla fragarioides, and Sanguisorba tenuifolia were distributed in HRG and CB. Pinus densiflora surrounded these two wetlands. Miscanthus sacchariflorus, Carex maximowiczii, and others were distributed in GJ, HM, and SB. Salix spp. and Alnus japonica surrounded these three wetlands. HRG and CB were smaller and steeper than GJ, HM, and SB. The annual average temperature of the region of $\mathrm{HRG}, \mathrm{CB}, \mathrm{HM}$, and "GJ and SB" in 2019 were $13.2 \pm 2.7^{\circ} \mathrm{C}, 13.2 \pm 2.8^{\circ} \mathrm{C}$, $13.8 \pm 2.5^{\circ} \mathrm{C}$, and $15.4 \pm 2.3^{\circ} \mathrm{C}$ (mean $\pm \mathrm{SE}$ ), respectively. The annual total precipitation of the region of HRG, CB, HM, and "GJ and SB" in 2019 were 919.5 $\mathrm{mm}, 914.8 \mathrm{~mm}, 1190.6 \mathrm{~mm}$, and $1536.1 \mathrm{~mm}$, respectively. All meteorological data of HRG, CB, HM, and "GJ and SB" were from stations in Incheon, Suwon, Hapcheon, and Yangsan, respectively (Korea Meteorological Administration 2019). 


\section{Field survey}

Survey was conducted during the period from September to October in 2019. A total of 47 quadrats in $2 \mathrm{~m} \times$ $2 \mathrm{~m}$ were randomly established for 5 study sites considering the range of $M$. japonica community distribution in each wetland (8 quadrats in HRG, 3 quadrats in CB, 16 quadrats in GJ, 10 quadrats in $\mathrm{HM}$, and 10 quadrats in SB). Quadrats were installed to satisfy the distance of $8 \sim 10 \mathrm{~m}$ between quadrats. Average height, density, and coverage of all herbal plants including $M$. japonica were measured in each quadrat, and relative coverage of $M$. japonica were calculated. Light intensity was measured at the top of $M$. japonica at five spots in each quadrat and open area with light intensity meter (LI-250A light meter, LI-COR), then relative light intensity (RLI) was calculated. Measuring light intensity was conducted in the afternoon. Soil samples were collected in each quadrat, blending 4 subsamples at $0 \sim 15-\mathrm{cm}$ depth after removal of litter.

\section{Soil properties analyses}

All fresh soil samples were passed through a 2-mm sieve to remove small particles of any plant and gravel. Soil water content (SWC) was measured after samples were dried at $105^{\circ} \mathrm{C}$ in an oven (Kim et al. 2004). The organic matter content in the soil samples was determined by loss on ignition (LOI) at $550^{\circ} \mathrm{C}$ for $4 \mathrm{~h}$ (Boyle 2004). The $\mathrm{pH}$ and electrical conductivity (EC) of fresh soil were measured in a 1:5 soil/distilled water suspension using a $\mathrm{pH}$ meter (model portable AP63 meters, Accumet) and a conductivity meter (model starter 300C, OHAUS), respectively. $\mathrm{NO}_{3}-\mathrm{N}$ and $\mathrm{NH}_{4}-\mathrm{N}$ in fresh soil samples were extracted with $2 \mathrm{M} \mathrm{KCl}$ solution (Keeney and Nelson 1982) and $\mathrm{PO}_{4}-\mathrm{P}$ was extracted with Bray No. 1 solution (Bray and Kurtz 1945). $\mathrm{NO}_{3}-\mathrm{N}, \mathrm{NH}_{4}-\mathrm{N}$, and $\mathrm{PO}_{4}-\mathrm{P}$ contents of soil were determined by hydrazine method (Kamphake et al. 1967), indo-phenol method (Solorzano 1969), and ascorbic acid reduction method (Murphy and Riley 1962), respectively. For exchangeable cation $\left(\mathrm{K}^{+}\right.$, $\mathrm{Ca}^{2+}, \mathrm{Na}^{+}$, and $\mathrm{Mg}^{2+}$ ) contents in fresh soil samples, cations were extracted with $1 \mathrm{M}$ ammonium acetate solution (Knudsen and Peterson 1982), then measured by an atomic absorption spectrometer (model AA240FS, Varian).

\section{Statistical analysis}

To figure out the difference of growth characteristics of $M$. japonica between high and low altitude wetlands, $t$ test was conducted after testing the data for normal distribution by Shapiro-Wilk test (Shapiro and Wilk 1965) with $R$ (ver. 3.6.3) (R Core Team 2018). If the data did not follow normality, we used Mann-Whitney $U$ test (Mann and Whitney 1947). Preliminary analysis using detrended correspondence analysis (DCA) suggested a linear response (the length of first axes $=1.35$ ) to analyze the relationship between vegetation and environmental factors. To identify the correlation of environmental factors with growth characteristics of $M$. japonica, a redundancy analysis (RDA) was conducted with R. Average height, density, and coverage of $M$. japonica were used for the analysis. Then, we conducted Monte-Carlo permutation test with 999 permutations to determine the major environmental factors affecting the growth characteristics of M. japonica. After that, the correlation analysis was carried out using IBM SPSS Statistics (ver. 23) in order to identify the relationship among each environmental factor and growth characteristics. Significance level was 0.05 for all performed statistical tests.

\section{Results}

Patterns of distribution and growth of $M$. japonica according to latitude

The locations of $M$. japonica habitats in South Korea were distributed throughout the country except the southwestern region (Fig. 1). Relative coverage of $M$. japonica was smaller in low latitude wetlands (HRG $54.7 \pm$ 6.1\%; CB 75.2 $\pm 5.3 \%$ ) than in high latitude wetlands (G) $87.3 \pm 2.0 \%$; HM $90.2 \pm 2.4 \%$; and SB $98.6 \pm 0.4 \%$ ). In addition, density and coverage of $M$. japonica were smaller in high latitude wetlands than in low latitude wetlands (Fig. 2).

\section{Environmental characteristics of $M$. japonica habitats}

The ranges of SWC and LOI were $27.82 \sim 83.01 \%$ and $5.45 \sim 68.48 \%$ respectively, and it showed that $M$. japonica lives in a broad range of distribution of soil moisture and organic matter content (Fig. 3). The distribution of $M$. japonica was identified in the range of 3.99 5.60 of soil $\mathrm{pH}$, showing acidic condition of habitats of $M$. japonica. The range of EC was $15.87 \sim 82.70 \mu \mathrm{S} / \mathrm{cm}$. RLI was distributed in a range of 5.86 97.25\%, and RLI of sites was divided into two ranges (5.85 34.30\% and 57.61 97.25\%), according to the presence of trees. The ranges of $\mathrm{NO}_{3}-\mathrm{N}, \mathrm{PO}_{4}-\mathrm{P}$, and $\mathrm{NH}_{4}-\mathrm{N}$ were $0 \sim 3.54 \mathrm{mg} / \mathrm{kg}, \quad 0 \sim 2.23 \mathrm{mg} / \mathrm{kg}$, and $0.63 \sim 89.75 \mathrm{mg} / \mathrm{kg}$, respectively, and $\mathrm{NH}_{4}-\mathrm{N}$ showed relatively high content. The ranges of $\mathrm{Ca}^{2+}, \mathrm{K}^{+}, \mathrm{Na}^{+}$, and $\mathrm{Mg}^{2+}$ were $13.24 \sim 435.54 \mathrm{mg} / \mathrm{kg}, \quad 33.91 \sim 286.24 \mathrm{mg} / \mathrm{kg}$, $10.17 \sim 93.00 \mathrm{mg} / \mathrm{kg}$, and $19.65 \sim 202.56 \mathrm{mg} / \mathrm{kg}$, respectively. Among exchangeable cations, $\mathrm{Na}^{+}$content was relatively low compared to $\mathrm{Ca}^{2+}, \mathrm{K}^{+}$, and $\mathrm{Mg}^{2+}$ content.

\section{Relationship between growth characteristics of $M$. japonica and environmental characteristics}

The redundancy analysis (RDA) ordination displayed scores for all of the quadrats with the arrows indicating the relative directions and strengths of the gradients of environmental factors (Fig. 4). The first two axes 
(a)

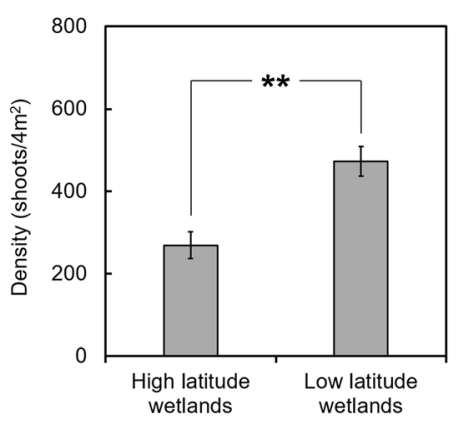

(b)

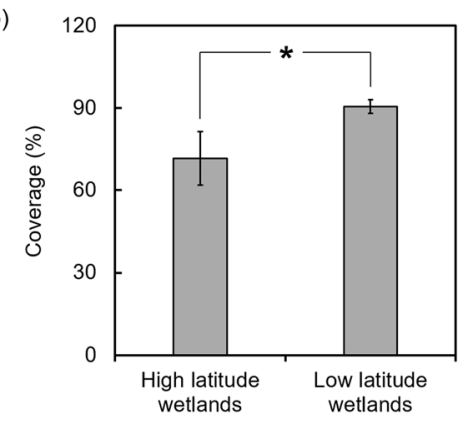

Fig. 2 Differences in density (a) and coverage (b) of M. japonica between high and low latitude wetlands. ${ }^{*} p<.05,{ }^{* *} p<.01$

explained $53.1 \%$ of the variance. SWC was the most important factor contributing to the first axis with 0.78 (Monte-Carlo permutation test with 999 permutations, $F=23.0, p<0.001)$. LOI contributed to the first axis with 0.75 but not statistically significant $(F$ $=0.4, p=0.55)$. Relative light intensity was also the major environmental factor with 0.75 of contribution to the first axis $(F=7.8, p<0.01)$, and $\mathrm{Ca}^{2+}$ content was statistically significant $(F=4.6, p<0.05)$. The rest of environmental factors did not have statistically significant effects on the growth of $M$. japonica. The quadrats of low latitude wetlands tended to follow the arrows of SWC, LOI, and RLI, while the quadrats of high latitude wetlands were distributed the opposite side to SWC, LOI, and RLI.

Correlation between the vegetational characteristics including density and coverage of $M$. japonica and environmental factors in all quadrats was analyzed (Table 1). As a result of the analysis, soil water content, LOI, and relative light intensity showed high correlations with density $(R=0.568,0.550,0.547$, respectively, $p<0.01)$ and coverage of $M$. japonica $(R$ $=0.495,0.385,0.514$, respectively, $p<0.01)$. Within the environmental characteristics, soil water content and LOI $(R=0.934, p<0.01)$, soil water content with $\mathrm{Na}^{+}(R=0.527, p<0.01)$, soil water content
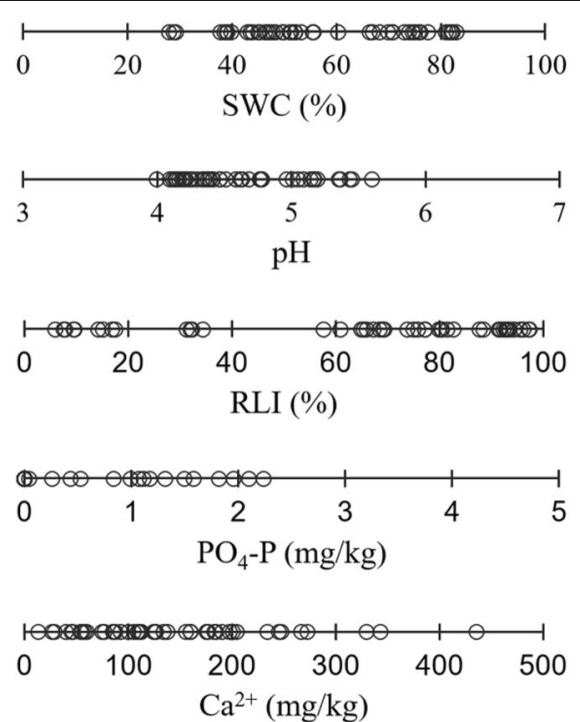

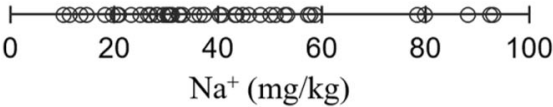
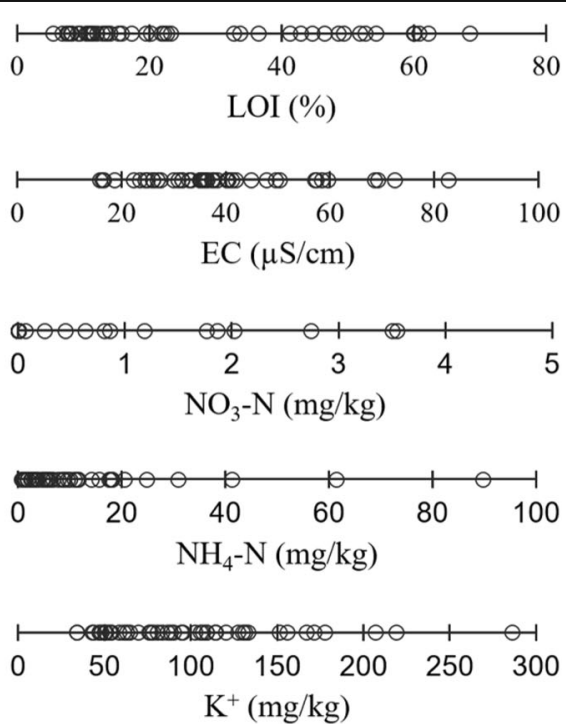

\begin{tabular}{|c|c|c|c|c|}
\hline-1 & 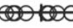 & $\theta+$ & 1 & \\
\hline 50 & 100 & 150 & 200 & 250 \\
\hline
\end{tabular}

Fig. $3 \mathrm{M}$. japonica distribution patterns according to environmental characteristics. The circles on the line represent the sample distribution (quadrat locations) on the gradient of corresponding environmental factors 


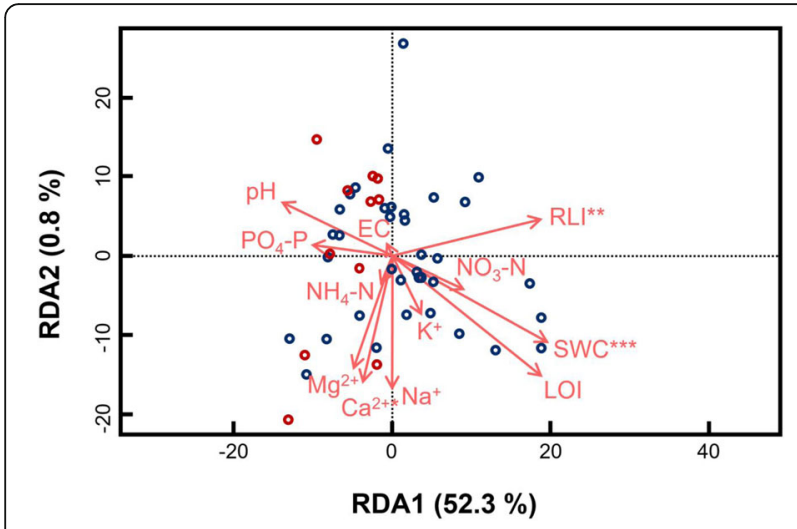

Fig. 4 Redundancy analysis (RDA) of vegetation and environmental characteristics of $M$. japonica. Red circle, quadrats in high latitude wetlands; blue circle, quadrats in low latitude wetlands; SWC, soil water content; LOI, loss on ignition; EC, electrical conductivity; RLI, relative light intensity. ${ }^{*} p<.05,{ }^{* *} p<.01,{ }^{* *} p<.001$

and $\mathrm{pH}(R=-0.523, p<0.01)$, and LOI with $\mathrm{pH}(R$ $=-0.600, p<0.01)$ were highly correlated.

\section{Discussion}

In our survey, the most important environmental factors for $M$. japonica growth were soil water content, loss on ignition, and relative light intensity (Fig. 4, Table 1).
Additionally, $M$. japonica habitats showed relatively low range of $\mathrm{pH}$, and even the locations where $M$. japonica showed vigorous growth had low pH (Fig. 3, Table 1). Considering that the distribution range of $\mathrm{pH}$ of other wetland plants is 5.25 7.26 (Lee et al. 2007; Jeon et al. 2013), low $\mathrm{pH}$ condition seems to be important for $M$. japonica population. In peat wetland, thick organic matter layer consisting of peat could keep moisture well without spilling it, conserving high level of soil moisture content, and creating an anaerobic environment on the ground surface and the around of rhizome (Mitsch and Gosselink 2015). In this anaerobic environment, bacteria cannot actively progress decomposition and nitrogen fixation which demand $\mathrm{H}^{+}$consummation, and thereby acidic environment could be established (Moore and Dalva 1997). Since most plants cannot grow well in the acidic environment (Pinkerton and Simpson 1986; Rubio et al. 2002), there might be less competitive stress for plants which adapted to acidic conditions. Therefore, it is thought that $M$. japonica could exhibit active growth under acidic environments with low competitive stress because it has high tolerance for low $\mathrm{pH}$ condition.

In addition to soil water content and $\mathrm{pH}$, relative light intensity (RLI) was also one of the most influential environmental factors for M. japonica growth (Fig. 4, Table 1). In particular, most $M$. japonica habitats showed over

Table 1 Pearson's correlation coefficients on vegetation and environmental characteristics of M. japonica $(n=47)$

\begin{tabular}{|c|c|c|c|c|c|c|c|c|c|c|c|c|c|c|c|}
\hline & Height & Density & Coverage & SWC & LOI & $\mathrm{pH}$ & EC & RLI & $\mathrm{NO}_{3}-\mathrm{N}$ & $\mathrm{PO}_{4}-\mathrm{P}$ & $\begin{array}{l}\mathrm{NH}_{4}^{-} \\
\mathrm{N}\end{array}$ & $\mathrm{Ca}^{2+}$ & $\mathrm{K}^{+}$ & $\mathrm{Na}^{+}$ & $\mathrm{Mg}^{2+}$ \\
\hline Height & & .117 & .165 & -.196 & $.296^{*}$ & .107 & .046 & .174 & -.067 & .004 & -.099 &. & -.164 & 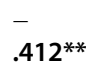 & $-372^{*}$ \\
\hline Density & & & $.622 * *$ & $.568^{* *}$ & $.550 * *$ & $-.406^{* *}$ & $\begin{array}{l}- \\
.021\end{array}$ & $.547^{* *}$ & .265 & $-.294^{*}$ & -.043 & -.107 & .110 & .000 & -.142 \\
\hline Coverage & & & & $.495^{* *}$ & $.385^{* *}$ & -.195 & $\begin{array}{l}- \\
.114\end{array}$ & $.514^{* *}$ & 3194 & $-.303^{*}$ & .050 & .025 & .050 & .067 & .030 \\
\hline SWC & & & & & $.934^{* *}$ & $-{ }^{-} 523^{* *}$ & .071 & $.456^{* *}$ & $.489 * *$ & -.180 & $.375^{* *}$ & $.373^{* *}$ & $.518^{* *}$ & $.527^{* *}$ & .230 \\
\hline LOI & & & & & & $-600^{* *}$ & .096 & $.428^{* *}$ & $.489 * *$ & -.195 & .261 & $.342^{*}$ & $.416^{* *}$ & $.487^{* *}$ & .219 \\
\hline $\mathrm{pH}$ & & & & & & &.- & -.135 & $.369 *$ & $.413^{* *}$ & .073 & .204 & .091 & .151 & $.318^{*}$ \\
\hline EC & & & & & & & & -.203 & .155 & $.323^{*}$ & .202 & -.108 & .239 & .042 & -.208 \\
\hline RLI & & & & & & & & & .166 & $-411^{* *}$ & -.131 & .028 & .003 & -.061 & .075 \\
\hline $\mathrm{NO}_{3}-\mathrm{N}$ & & & & & & & & & & -.145 & .264 & .062 & .185 & .170 & -.049 \\
\hline $\mathrm{PO}_{4}-\mathrm{P}$ & & & & & & & & & & & $.366^{*}$ & .233 & $.543^{* *}$ & $.356^{*}$ & .165 \\
\hline $\mathrm{NH}_{4}-\mathrm{N}$ & & & & & & & & & & & & $.310^{*}$ & $.569^{* *}$ & $.558^{* *}$ & .145 \\
\hline $\mathrm{Ca}^{2+}$ & & & & & & & & & & & & & $.467^{* *}$ & $.811^{* *}$ & $.938^{* *}$ \\
\hline $\mathrm{K}^{+}$ & & & & & & & & & & & & & & $.724^{* *}$ & .287 \\
\hline $\mathrm{Na}^{+}$ & & & & & & & & & & & & & & & $.696 * *$ \\
\hline $\mathrm{Mg}^{2+}$ & & & & & & & & & & & & & & & \\
\hline
\end{tabular}


$60 \%$ of RLI (Fig. 3). This result is consistent with Hirata and Tsuyuzaki (2016), reporting the light as a major environmental factor for the growth of $M$. japonica. The high RLI is thought to be important for $M$. japonica growth because relatively high light intensity would enable their vigorous growth with high photosynthesis activity. Moreover, M. japonica were distributed predominantly in montane wetlands of temperate zone of low latitude with higher density and coverage than high latitude in Korea (Fig. 2). Meanwhile, montane wetlands show lower annual temperature than lowland wetlands in the same latitude since they are located in higher altitude (Hoek et al. 2019), and the low temperature of montane wetlands is beneficial for peat formation and maintenance because of slow decomposition speed (Mitsch and Gosselink 2015).

Because of these several environmental characteristics, it is thought to be possible that $M$. japonica becomes a dominant species in high altitude montane wetlands in temperate zone of low latitude in Korea. Furthermore, as environmental factors affected the growth and development of $M$. japonica, it is likely that the domination of $M$. japonica could cause positive feedback effect, making the environment more suitable for their growth. In particular, their vigorous growth might contribute to the maintenance of acidic condition in montane peat wetland. Indeed, the density of $M$. japonica and $\mathrm{pH}$ had a remarkable negative correlation (Table 1). Molinia japonica largely contributes to the productivity of montane wetlands with huge biomass production of $1200 \sim 1370 \mathrm{~g} / \mathrm{m}^{2}$ in Janggun wetland at Mt. Geumjeong (Son 2020). Thus, huge shoot litter of $M$. japonica covers the floor and forms a new peat layer in winter. Because of low decomposition rate in montane wetlands (Kim 2005; Mitsch and Gosselink 2015), annual large supply of $M$. japonica shoot litter could stimulate peat formation. As the peat layer with high content of organic matter can hold water for long time (Mitsch and Gosselink 2015), the low pH condition could be easily formed in accordance with anaerobic environment. Therefore, high RLI and high altitude would contribute to more developed $M$. japonica population leading to more acidic environments, which further stimulates their growth performance. Further, it seems that the balance between the productivity of $M$. japonica and $\mathrm{pH}$ is necessary for the maintenance of this environment, and the vegetation structure of $M$. japonica dominant wetlands is formed with priority given to this balanced state. Known as a late colonizer, $M$. japonica adapted less to strong solar radiation including ultraviolet than an early colonizer (Hirata and Tsuyuzaki 2016), so that it would make peat layer first and drop $\mathrm{pH}$ when it settles in new place. To elaborate the relationship between $M$. japonica growth and $\mathrm{pH}$ condition, further examination in detail would be necessary for the effect of $\mathrm{pH}$ on the growth of $M$. japonica, and also vice versa.

Even though coverage and density of Molinia japonica were high in low latitude in Korea, we could not figure out which environmental factor is responsible for the optimal distribution range of this plant. When we consider productivity of $M$. japonica based on coverage and density data (Fig. 2), this might be annual temperature change. This could be figured out more through studies on environmental variables and common garden experiment.

\section{Conclusions}

In this study, field survey was conducted in several montane wetlands in order to figure out the important environmental characteristics for the growth and the formation of dominant communities of $M$. japonica in montane wetlands. Soil water content and loss on ignition were major environmental factors in $M$. japonica habitats, and $\mathrm{pH}$ was highly correlated with these two factors. Also, relative light intensity played an important role by providing enough light energy for photosynthesis of $M$. japonica. Understanding of the major environmental factors for the growth of $M$. japonica could be used for the further research about the mechanism of retaining acidic environment autonomously in montane wetlands in temperate zone.

\section{Abbreviations \\ asl: Above sea level; CB: Wetland in Mt. Chilbo; EC: Electrical conductivity; GJ: Wetland in Mt. Geumjeong; HM: Wetland in Mt. Hwangmae; HRG: Wetland in Mt. Horyonggok; LOI: Loss on ignition; RDA: Redundancy analysis; RLI: Relative light intensity; SB: Wetland in Mt. Sinbul; SWC: Soil water content}

\section{Acknowledgements}

We would like to thank Bo Eun Nam, Hyekyung Park, and Ga-yeon Son in Seoul National University for supporting in the field survey and the soil analysis.

\section{Authors' contributions}

YSC performed the field survey, analyzed experimental data, and wrote the manuscript draft. HJP participated in the design of the study, conducted field survey, and edited the manuscript. JGK conceived the research idea and reviewed and edited the manuscript. The authors read and approved the final manuscript.

\section{Funding}

National Research Foundation of Korea (NRF) grant funded by the Korea government (MSIT) (No. 2018R1A2B2002267)

\section{Availability of data and materials}

The datasets generated during and/or analyzed during the current study are available from the corresponding author on reasonable request.

\section{Competing interest}

The authors declare that they have no competing interests.

Ethics approval and consent to participate

Not applicable.

Consent for publication

Not applicable. 
Received: 26 October 2020 Accepted: 10 December 2020

Published online: 06 January 2021

\section{References}

Ahn KS, Kim HS, Kim JG, editors. Wetlands. Seoul: Life Science Publishing Co; 2016.

Berendse F. Effects of dominant plant species on soils during succession in nutrient-poor ecosystems. Biogeochemistry. 1998;42:73-88.

Boyle J. A comparison of two methods for estimating the organic matter content of sediments. J Paleolimnol. 2004;31:125-7.

Bray RH, Kurtz LT. Determination of total, organic and extracted forms of phosphorus in soil. Soil Sci. 1945;59:39-46.

Choung Y, Lee WT, Joo KY, Lee JS, Seo H, Lee KE, Seo A. Review on the herbaceous flora of Keunyongneup in Mt. Daeam, Korea. Korea J Basic Sci. 2009:20:205-27.

Crowe EA, Clausnitzer RR. Mid-montane wetland plant associations of the Malheur, Umatilla and Wallowa-Whitman national forests. Portland: USDA Forest Service; 1997.

He XY, Wang KL, Zhang W, Chen ZH, Zhu YG, Chen HS. Positive correlation between soil bacterial metabolic and plant species diversity and bacterial and fungal diversity in a vegetation succession on Karst. Plant Soil. 2008;307: $123-34$.

Hirata AKB, Tsuyuzaki S. The response of an early (Rhynchospora alba) and a late (Molinia japonica) colonizer to solar radiation in a boreal wetland after peat mining. Wetl Ecol Manag. 2016;24:521-32.

Hoek Y, Tuyisingize D, Eckardt W, Garriga N, Derhé MA. Spatial variation in anuran richness, diversity, and abundance across montane wetland habitat in Volcanoes National Park. Rwanda. Ecol Evol. 2019;9(7):4220-30.

Jeon SH, Kim H, Nam JM, Kim JG. Habitat characteristics of sweet flag (Acorus calamus) and their relationships with sweet flag biomass. Landsc Ecol Eng. 2013;9:67-75

Kamphake $L$, Hannah SA, Cohen JM. Automated analysis for nitrate by hydrazine reduction. Water Res. 1967;1:205-16.

Keeney DR, Nelson DW. Nitrogen-inorganic forms. In: Page AL, Miller RH, Keeney DR, editors. Methods of soil analysis Part 2. Wisconsin: American Society of Agronomy; 1982.

Kim JG. Nutrient dynamics in montane wetlands, emphasizing the relationship between cellulose decomposition and water chemistry. J Wet Res. 2005;7(4): 33-42.

Kim JG, Park JH, Choi BJ, Sim JH, Kwon GJ, Lee BA, Ju EJ. Methods in ecology. Seoul: Bomoondang; 2004. (in Korean).

Kim JW, Kim JH, Jegal JC, Lee YK, Choi KR, Ahn KH, Han SU. Vegetation of Mujechi moor in Ulsan: actual vegetation map and Alnus japonica population. Korean J Ecol. 2005;28(2):99-103.

Kim T, Kim T, Kim J, Lee J, Lim J, Lee C, Park J. A study on soil characteristics for conservation and management of mountain wetlands (II). Republic of Korea: National Institute of Environmental Research; 2015.

Kim T, Yang B, Lee J, Yang H, Park S, Lee J, Lee J, Baek C, Lim J, Kang N, Park J. A study on soil characteristics for conservation and management of mountain wetlands(I). Republic of Korea: National Institute of Environmental Research; 2014.

Knudsen D, Peterson GA. Lithium, sodium and potassium. In: Page AL, Miller RH, Keeney DR, editors. Methods of soil analysis part 2. Wisconsin: American Society of Agronomy; 1982.

Koerselman W, Bakker SA, Blom M. Nitrogen, phosphorus and potassium budgets for two small fens surrounded by heavily fertilized pastures. J Ecol. 1990;78: 428-42.

Korea Meteorological Administration. (2019) https://www.weather.go.kr/weather/ main.jsp. Accessed 10 Mar 2020.

Koukoura Z, Mamolos AP, Kalburtij KL. Decomposition of dominant plant species litter in a semi-arid grassland. Appl Soil Ecol. 2003;23:13-23.

Lee BA, Kwon GJ, Kim JG. The optimal environmental ranges for wetland plants: II. Scirpus tabernaemontani and Typha latifolia. J Ecol Field Biol. 2007;30(2): 151-9.

Lee TB. Colored flora of Korea. Hyangmunsa: Seoul; 2003. (in Korean).

Mann $\mathrm{HB}$, Whitney DR. On a test of whether one of two random variables is stochastically larger than the other. Ann Math Stat. 1947;18:50-60.

Mitsch WJ, Gosselink JG. Wetlands. 5th ed. New Jersey: John Wiley \& Sons, Inc.; 2015.

Moon SK, Koo BH. A study on Korea inland wetland boundary delineation. J Korean Env Res Tech. 2014;17(2):15-30.
Moore TR, Dalva M. Methane and carbon dioxide exchange potentials of peat soils in aerobic and anaerobic laboratory incubations. Soil Biol Biochem. 1997;29(8):1157-64

Mulhouse JM, Steven DD, Lide RF, Sharitz RR. Effects of dominant species on vegetation change in Carolina bay wetlands following a multi-year drought. J Torrey Bot Soc. 2005;132(3):411-20.

Murphy J, Riley JP. A modified single solution method for the determination of phosphate in natural waters. Anal Chim Acta. 1962;27:31-6.

Park J, Hong MG, Kim JG. Relationship between early development of plant community and environmental condition in abandoned paddy terraces at mountainous valleys in Korea. J Ecol Environ. 2013;36(2):131-40.

Park S, An BR, Jang SY, Park SJ. Diversity of Moojechineup's flora. Korean J PI Taxon. 2011;41(4):370-82.

Pinkerton A, Simpson JR. Interactions of surface drying and subsurface nutrients affecting plant growth on acidic soil profiles from an old pasture. Aust J Exp Agric. 1986;26:681-9.

R Core Team. R: a language and environment for statistical computing. Vienna: $R$ foundation for statistical computing; 2018.

Rubio R, Borie F, Schalchli C, Castillo C, Azco'n R. Plant growth responses in natural acidic soil as affected by arbuscular mycorrhizal inoculation and phosphorus sources. J Plant Nutr. 2002;25(7):1389-405.

Ryan ME, Palen WJ, Adams MJ, Rochefort RM. Amphibians in the climate vise: loss and restoration of resilience of montane wetland ecosystems in the western US. Front Ecol Environ. 2014;12(4):232-40.

Shapiro SS, Wilk MB. An analysis of variance test for normality (complete samples). Biometrika. 1965;52:591-611.

Solorzano L. Determination of ammonia in natural waters by the phenol hypochlorite method. Limnol Oceanogr. 1969;14:799-801.

Son GY. Analysis of the water level change for the conservation of Janggun montane wetland. Seoul: Seoul National University; 2020.

Tscharntke T. Fragmentation of Phragmites habitats, minimum viable population size, habitat suitability, and local extinction of moths, midges, flies, aphids, and birds. Conserv Biol. 1992;6(4):530-6.

Yi GC, Nam JC. Management program and ecological characteristics of forest wetlands located at Sinbul mountain. J Wet Res. 2008;10(2):1-14.

\section{Publisher's Note}

Springer Nature remains neutral with regard to jurisdictional claims in published maps and institutional affiliations.

Ready to submit your research? Choose BMC and benefit from:

- fast, convenient online submission

- thorough peer review by experienced researchers in your field

- rapid publication on acceptance

- support for research data, including large and complex data types

- gold Open Access which fosters wider collaboration and increased citations

- maximum visibility for your research: over $100 \mathrm{M}$ website views per year

At BMC, research is always in progress.

Learn more biomedcentral.com/submissions 